\title{
"Digitalization as a development factor of innovative-active university"
}

\begin{tabular}{|c|c|}
\hline AUTHORS & $\begin{array}{l}\text { Volodymir Ponomarenko (D) } \\
\text { R } \\
\text { Olena Rayevnyeva (i) } \\
\mathbb{R} \\
\text { Volodymyr Yermachenko } \\
\text { Iryna Aksonova (D) } \\
\text { R } \\
\text { Olha Brovko (D) }\end{array}$ \\
\hline ARTICLE INFO & $\begin{array}{l}\text { Volodymir Ponomarenko, Olena Rayevnyeva, Volodymyr Yermachenko, Iryna } \\
\text { Aksonova and Olha Brovko (2021). Digitalization as a development factor of } \\
\text { innovative-active university. Problems and Perspectives in Management, 19(4), } \\
\text { 213-231. doi:10.21511/ppm.19(4).2021.18 }\end{array}$ \\
\hline DOI & http://dx.doi.org/10.21511/ppm.19(4).2021.18 \\
\hline RELEASED ON & Tuesday, 09 November 2021 \\
\hline RECEIVED ON & Friday, 11 June 2021 \\
\hline ACCEPTED ON & Tuesday, 17 August 2021 \\
\hline LICENSE & $\begin{array}{l}(\mathrm{cc}) \mathrm{EY} \\
\text { This work is licensed under a Creative Commons Attribution } 4.0 \text { International } \\
\text { License }\end{array}$ \\
\hline JOURNAL & "Problems and Perspectives in Management" \\
\hline ISSN PRINT & $1727-7051$ \\
\hline ISSN ONLINE & $1810-5467$ \\
\hline PUBLISHER & LLC "Consulting Publishing Company "Business Perspectives" \\
\hline FOUNDER & LLC "Consulting Publishing Company "Business Perspectives" \\
\hline
\end{tabular}

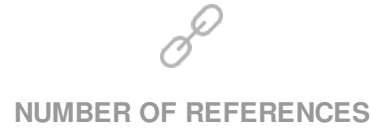

48

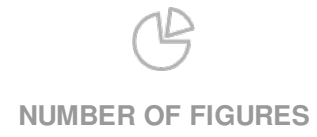

10

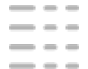

NUMBER OF TABLES

4

(C) The author(s) 2022. This publication is an open access article. 


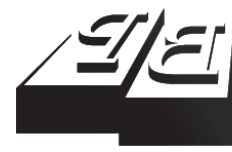

\section{BUSINESS PERSPECTIVES}

()

LLC "CPC "Business Perspectives" Hryhorii Skovoroda lane, 10, Sumy, 40022, Ukraine www.businessperspectives.org
Received on: $11^{\text {th }}$ of June, 2021 Accepted on: $17^{\text {th }}$ of August, 2021 Published on: $9^{\text {th }}$ of November, 2021

(C) Volodymir Ponomarenko, Olena Rayevnyeva, Volodymyr Yermachenko, Iryna Aksonova, Olha Brovko, 2021

Volodymir Ponomarenko, D.Sc. (Economics), Professor, Simon Kuznets Kharkiv National University of Economics, Ukraine.

Olena Rayevnyeva, D.Sc. (Economics), Professor, Simon Kuznets Kharkiv National University of Economics, Ukraine.

Volodymyr Yermachenko, Ph.D. (Economics), Professor, Simon Kuznets Kharkiv National University of Economics, Ukraine.

Iryna Aksonova, Ph.D. (Economics), Associate Professor, Simon Kuznets Kharkiv National University of Economics, Ukraine. (Corresponding author)

Olha Brovko, Ph.D. (Economics), Associate Professor, Simon Kuznets Kharkiv National University of Economics, Ukraine.
Volodymir Ponomarenko (Ukraine), Olena Rayevnyeva (Ukraine), Volodymyr Yermachenko (Ukraine), Iryna Aksonova (Ukraine), Olha Brovko (Ukraine)

\section{AS A DEVELOPMENT FACTOR OF INNOVATIVE-ACTIVE UNIVERSITY}

\begin{abstract}
A characteristic feature of the XXI century is the emergence of the digital society phenomenon, which significantly changes all processes in higher education. The implementation of innovations into university activity, creation of its digital culture, and digital environment are the key features of an innovative-active university (IAU) and factors of its development. The paper aims to develop a strategy and innovative-indicative measures for digitalization of IAU activities based on the study of society's digital maturity. Index, rating, comparative analyzes, and decomposition method were used. It is determined that Ukraine has a significant gap in comparison with the developed countries in terms of digital maturity of society and occupies lower than average positions in international informatization indices. To assess the state of digitalization processes in Ukraine, government measures for the development of digital culture were analyzed, the limitations and triggers of society digitalization are identified. It is proved that the digitalization of education has a dominant impact on the overall level of digital competitiveness. That is, the introduction of information and communication technologies in the IAU activity is an urgent task of its management. The digitalization strategy of S.Kuznets KhNUE in accordance with its educational, scientific and technical, marketing, and international activities was created. The proposed strategy is based on a systemic understanding of digitalization processes, which makes it possible to increase the degree of their controllability. A set of innovative and indicative measures was developed, which constitute the tactical contour of IAU digital process management.
\end{abstract}

\section{Keywords}

university activity, digital culture, digitalization strategy, innovative and indicative measures

\section{JEL Classification I21, I25, I28}

\section{INTRODUCTION}

Contemporary conditions for the development of civilization in the XXI century are characterized by the emergence and intensification of digitalization, i.e. the global digital transformation of society. This process takes place in all spheres of life and involves the transition from offline to online mode. Among the areas of digitalization, digitalization of the economy and business, education and professions, financial market, labor market and trade, manufacturing, medical, insurance, and banking, etc. are especially developing in modern conditions.

As a phenomenon, digitalization has evolved from the automation process, where workflows are algorithmized and transferred to digital format. Digital transformation has the characteristics that put it on a higher stage of scientific and technological progress, namely: rethinking of the external communication model with partners and customers, which focuses on client's needs; emergence of a sharing business model of the company, transition from project management to Agile and Learn-technologies; changing the working model with informa- 
tion from the concept of Big Data to the Deep Machine Learning concept, based on the use of artificial intelligence and decision-making in terms of incomplete and asymmetric information; internal communications transformation and relations - outsourcing and freelancing.

The formation and development process of the digital society began in the late XX century, but the situation in 2019-2020, associated with the Covid-19 pandemic, accelerated this trend. According to Evergreen (2020), global investment in digital technologies and services by 2023 should amount to $\$$ 2.3 trillion. However, the coronavirus pandemic has been a trigger to intensify the efforts of business structures to implement digital technologies. More than 4,000 business leaders around the world were surveyed according to InfoCity (2020), and eight out of ten organizations have accelerated their digital transformation programs in 2020.

Information technology, digital literacy, and business digitalization are the main innovative areas of development of society and significantly change the educational process in general. The need for widespread use of modern information technologies and services in various types of university activities that work with Big Data, creation of a systematic digital environment for university management, formation of corporate information and educational system, and protection of corporate information are becoming the main tasks of university management. In addition, the adaptation of national higher education institutions to the changing needs of key stakeholders, namely consumers of educational services, potential employers, and government organizations, requires an innovative search or development of appropriate tools, approaches, strategies to maintain high-quality education in the new environment. All these are the main features of an innovative-active university (IAU), by which Yevseiev et al. (2020) imply an entrepreneurial organization that has resource readiness to contribute to accelerated socio-economic development through the intensive transfer of knowledge and technologies generated at the university based on partnership with stakeholders.

Thus, digitalization is becoming a driving force for development and a factor in the competitiveness of an innovative-active university in the national and international educational market.

\section{LITERATURE REVIEW}

Nowadays, many scientists in their research focus on the problems and prospects of society and the national economy, taking into account the digitalization potential. Thus, Kolyadenko (2016) analyzed the history of the concept of the digital economy and noted that the founders of this category identified three main components of such an economy: supporting infrastructure, e-business, and e-commerce. Based on this, modern research conducted using the digital economy can quickly adapt to the real economy and enable real sectors of the economy to quickly find ways out of different types of crises. Kokh and Kokh (2019) propose to consider the concept of the digital economy on three levels: the sector where information and communication technologies (ICT) are developed, the sector of activities that cannot function without ICT use, and the sector of other activities that require digitization. Dyba and Gernego (2018), Kononova (2015),
Kraus et al. (2018), Liashenko and Vyshnevskyi (2018), Ochs and Riemann (2018) provide trends in the digital economy in the leading countries of the world and argue that modern processes of digital transformation of society are associated with business development models that use digital platforms. In addition, these platforms are being updated and emphasize the blockchain technologies usage in education.

Problems of assessing the level of development of the digital economy and society in the country are covered by Golovenchik (2018), Bakumenko and Minina (2020), Varlamova and Demianova (2020), as well as in studies of international organizations that use various indices. Thus, Golovenchik (2018) proposes to use rating analysis in the study of the digitalization level of the economy based on international indices. The UN Economic and Social Council (2020) determines digitization as one of the priority areas of the National Accounts 
Research Program and is working on the Digital Economy and Society Index, developing indicators for measuring digital transformation. Varlamova and Demianova (2020) analyze the growth rates and the state of the digital economy in the countries of the world and prove that the leading countries demonstrate high rates of digital development and diffusion of innovations in various spheres of social development. For example, the global index of digital competitiveness of a country contains the factor of knowledge, which includes indicators of talent, training, and education, scientific concentration. These components reflect the efforts of national universities to digitize their activities.

The emergence of the concept of a digital university is a phenomenon of the late XX-early XXI century. Thus, Jones and Goodfellow (2012) assess the impact of digital technologies on changes in university activities while McCluskey and Lynn Winter (2012) compare digital and traditional universities and show how the university has to adapt to the digital age while keeping what is most essential, namely the mission of learning. Lukianenko and Stepanenko (2018) note that the digital transformation of education is the driving force behind the sustainable development of universities around the world. It was noted that the concept of a digital university implies a radical change in corporate culture and digitalization of all processes at the university. The research of the digital future of universities is the focus of Johnston et al. (2018). Practical tools are offered for the academic and organizational development of a digital university. PwC (2018) confirms that modern university transformation must go through the development of effective digital strategies.

The main trends of digitalization of education are analyzed in the works of many scientists. Thus, Kadyrbaeva (2018) considers new approaches to the organization of learning and new learning solutions based on new formats of full-time and online learning. Areshonkov (2020) believes that higher education digitalization and the creation of digital universities is a response to today's challenges and defines a list of tasks for public administration and the leadership of a higher education institution (HEI) to spread domestic university digitalization. Korotenko (2020) pays attention to the issues of flexibility and mobility of learn- ing, especially in the context of digitalization and the functioning of HEI in force majeure (Covid-19 pandemic). Online education is seen as an innovation in education.

Habib et al. (2021) emphasize the need to create automated management and learning infrastructure in a modern university, aimed at improving the efficiency of teachers, staff, and university administration. Creation of an integrated digital platform for the university to interact with key stakeholders is proposed. Babin (2018) develops recommendations for building an integrated information environment of the university, which is focused on the management of internal business processes, individualization of learning, the use of online courses, and network collaboration with consumers of educational services.

Yevseiev et al. (2017) propose to apply an integrated indicator of service quality for users to assess the effectiveness of the corporate scientific and educational network, information protection within the corporate educational network. The practical use of the proposed indicator will allow to more accurately assess the effectiveness of data exchange protocols used in global IP networks, the economic network deployment, and maintenance costs, the cost of providing the required indicator of service quality, i.e. the digitization efficiency.

Thus, the formation of a digital university is an urgent task of the modern stage of transformation of the higher education system and it is considered as a factor in enhancing the innovative activity of the HEI. All this justifies the need to continue research in this direction, the development of new methodological approaches, strategies, and effective means of digitalization of the main types of activities of national HEI.

\section{AIM AND METHODOLOGY}

The paper aims to develop a strategy and innovative-indicative measures for the digitalization of IAU activities based on the study of society's digital maturity.

The methodological basis of the study is the concept of a digital university, which emerged at the 
beginning of the XXI century as a response to a radical change in the needs of the digital society.

A key feature of the concept is its focus on transforming all types of university activities, especially the form and content of education. The concept contains the main components:

1. Formation of the university management information system.

2. Creation of online support and implementation of digital technologies in the educational process.

3. Formation of key competencies for the needs of the digital economy.

4. Digital transformation of the university activities related to the formation of digital culture and the digital environment of the university.

The introduction of this concept in the practice of the university presupposes, first of all, the resource readiness of HEI to digitalize the processes and types of its activities, permanent collaboration with the main stakeholders, which is a characteristic feature of an innovative-active university.

The implementation of the concept of "digital university" primarily depends on effective tools for its implementation in the practice of activities, the main of which is the strategy of digitalization of the types of activities of HEI.

Based on this, a methodological approach to the development of a digitalization strategy for the main types of university activities is proposed, which is based on the following hypotheses:

1. The emergence of the phenomenon of "digitalization of higher education" is the result of new needs of stakeholders following the requirements of the development of the digital economy and digital society of the XXI century and acts as a trigger for the development of an innovative-active university.

2. The effectiveness of the digitalization process of higher education depends on a synergistic combination of initiatives from the state and the innovative-active behavior of a separate HEI.

3. To maintain the higher education quality under the influence of changing environmental conditions (force majeure, for example, the Covid-19 pandemic), it is necessary to establish the optimal balance between online and offline learning.

4. The effectiveness of the digital transformation of the university depends on the systemic implementation of digital technologies in all types of its activities.

Figure 1 shows a scheme of the methodical approach.

\section{RESULTS}

Next, the steps of the proposed methodical approach are considered in more detail.

Stage 1. The formation and development of the digital society are influenced by both the external and internal environment. In this regard, to develop effective measures to implement and disseminate the processes of digitalization of society and educational activities in the HEI, it is necessary to rely on current trends in the digital economy, which can be identified based on rating analysis of digital indexes.

The construction of ratings is a mathematical apparatus of various indicators and indicators convolution in compared values, so the use of rating analysis is in demand when conducting interstate comparisons. To assess the level of development of the digital economy or its components, various ratings are used, calculated based on the following indices: ICT Development Index (IDI), Digital Economy and Society Index (DESI), IMD World Digital Competitiveness Index (WDCI), Digital Evolution Index (DEI), Economy digitalization index Boston Consulting Group (e-Intensity), Networked Readiness Index (NRI), The UN Global E-Government Development Index (EGDI), E-Participation Index (EPART), Global Connectivity Index (GCI, Huawei), The Global Innovation Index (GII), and Global Competitiveness Index (WEF). 


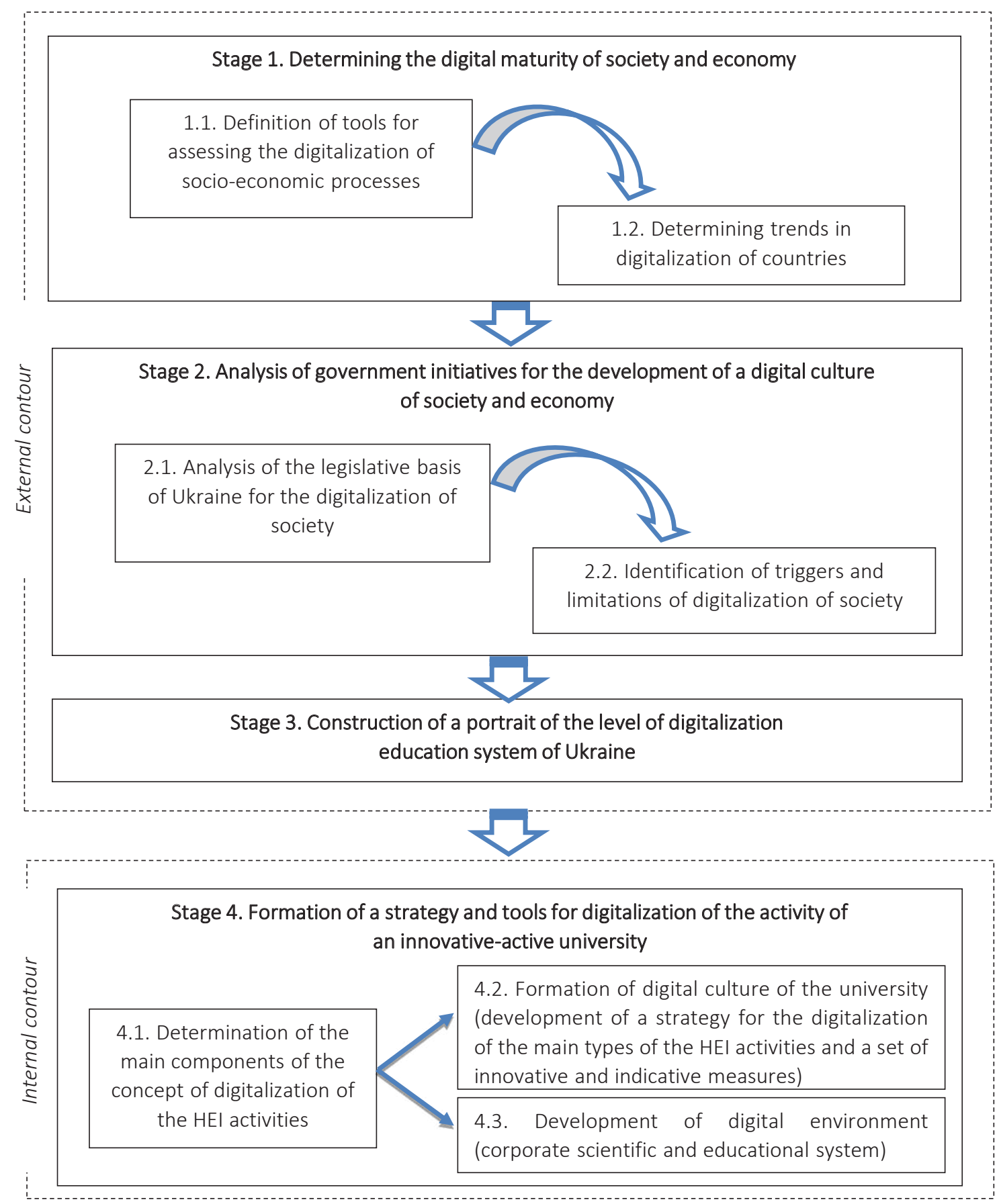

Figure 1. Scheme of the methodical approach to developing a digitalization strategy for the spheres of university activity

The level of digitalization of the Ukrainian economy and the ten best economies in the world, determined by Kokh and Kokh (2019), IMD World Competitiveness Center (2020), International Telecommunication Union (2017), Global connectivity index (2020), Dutta and Lanvin (2020), United Nations (2020), Schwab (2019), and World Intellectual Property Organization (2020) are presented in Table 1.
As can be seen from Table 1, Ukraine differs significantly from the highly innovative countries of the world in the level of digitalization and all indices occupy average and below-average ratings.

One of the indices on the basis of which one can get a systematic view of the digitalization of society and the impact of factors on the development of this process is the IMD World Digital 
Table 1. Ratings of the digital economy of the world according to various indices

\begin{tabular}{|c|c|c|c|c|c|c|c|c|c|}
\hline Country & IDI 2017 & WDCI 2020 & GCl 2020 & NRI 2020 & EGDI 2020 & EPART 2020 & GII 2020 & WEF 2019 & Mean \\
\hline USA & 16 & 1 & 1 & 8 & 9 & 1 & 3 & 2 & 5.13 \\
\hline Singapore & 18 & 2 & 2 & 3 & 11 & 6 & 8 & 1 & 6.38 \\
\hline Denmark & 4 & 3 & 5 & 2 & 1 & 9 & 6 & 10 & 5.00 \\
\hline Sweden & 11 & 4 & 4 & 1 & 6 & 41 & 2 & 8 & 9.63 \\
\hline Hong Kong SAR & 6 & 5 & 22 & 22 & 45 & 9 & 14 & 3 & 15.75 \\
\hline United Kingdom & 5 & 13 & 8 & 10 & 7 & 6 & 4 & 9 & 7.75 \\
\hline Finland & 22 & 10 & 6 & 6 & 4 & 14 & 7 & 11 & 10.00 \\
\hline Germany & 12 & 18 & 15 & 9 & 25 & 57 & 9 & 7 & 19.00 \\
\hline Ukraine & 79 & 58 & 52 & 64 & 69 & 46 & 45 & 85 & 62.25 \\
\hline
\end{tabular}

Table 2. Changes in the place of countries in the ranking of digital competitiveness

\begin{tabular}{|c|c|c|c|c|c|}
\hline Country & 2016 & 2019 & 2020 & Change in 2020 compared to 2016 & Change in 2020 compared to 2019 \\
\hline USA & 2 & 1 & 1 & $\uparrow 1$ & $\leftrightarrow$ \\
\hline Singapore & 1 & 2 & 2 & $\downarrow 1$ & $\leftrightarrow$ \\
\hline Denmark & 8 & 4 & 3 & $\uparrow 5$ & $\uparrow 1$ \\
\hline Sweden & 3 & 3 & 4 & $\downarrow 1$ & $\downarrow 1$ \\
\hline Hong Kong SAR & 11 & 8 & 5 & $\uparrow 6$ & $\uparrow 3$ \\
\hline$\ldots$ & $\ldots$ & $\ldots$ & $\ldots$ & $\ldots$ & $\ldots$ \\
\hline Mexico & 52 & 49 & 54 & $\downarrow 2$ & $\downarrow 5$ \\
\hline Peru & 58 & 61 & 55 & $\uparrow 3$ & $\uparrow 6$ \\
\hline Indonesia & 60 & 56 & 56 & $\uparrow 4$ & $\leftrightarrow$ \\
\hline Philippines & 46 & 55 & 57 & $\downarrow 11$ & $\downarrow 2$ \\
\hline Ukraine & 59 & 60 & 58 & $\downarrow 1$ & $\uparrow 2$ \\
\hline
\end{tabular}

Competitiveness Index (WDCI), which is calculated based on a study of capacity and readiness of 63 economies to implement digital technologies as economic transformations in society (IMD World Competitiveness Center, 2020).

The component structure of the rating, built based on WDCI in tuple form is as follows:

$$
W D C R=\langle K n ; T n ; F r\rangle,
$$

where WDCR - World Digital Competitiveness Rating, which shows the country's place in the development of digitalization level of society; $K n$ is a knowledge factor that covers the intangible infrastructure needed to discover, understand and build new technologies. This component includes indicators of talent, learning and education, and scientific concentration; $T n$ is a technology factor that quantifies the overall basis for the development of digital technologies. This component covers indicators of the regulatory and technological base; $F r$ - future readiness factor, which characterizes the level of readiness of the country to use digital transformation. This component includes indicators of business flexibility, adaptability, and IT integration.
Table 2 shows the level of development of digitalization of society on the basis of WDCR assessment.

In the rating of digital competitiveness of countries, Ukraine in 2020 compared to 2019 rose by 2 points and is now in 58th place among the 63 countries that participated in the indexation. As can be seen from Table 2, almost all countries, both those belonging to the cluster group of leaders and those to which the cluster group Ukraine belongs, have raised their positions on the digitalization of society over the past year. The top 5 countries have different approaches to digital competitiveness. Thus, the United States and Sweden aim at a balanced approach to acquiring knowledge, creating favorable conditions for technology development and readiness for innovation. Countries such as Singapore and Denmark give priority to one or two factors that make up the Digital Competitiveness Index.

In the further study of Ukraine's ranking by WDCI values and the formation of a portrait of the level of digitalization of higher education in Ukraine, emphasis will be placed on identifying the components of knowledge and its sub-factors. 
Source: State Statistics Service of Ukraine (2020).

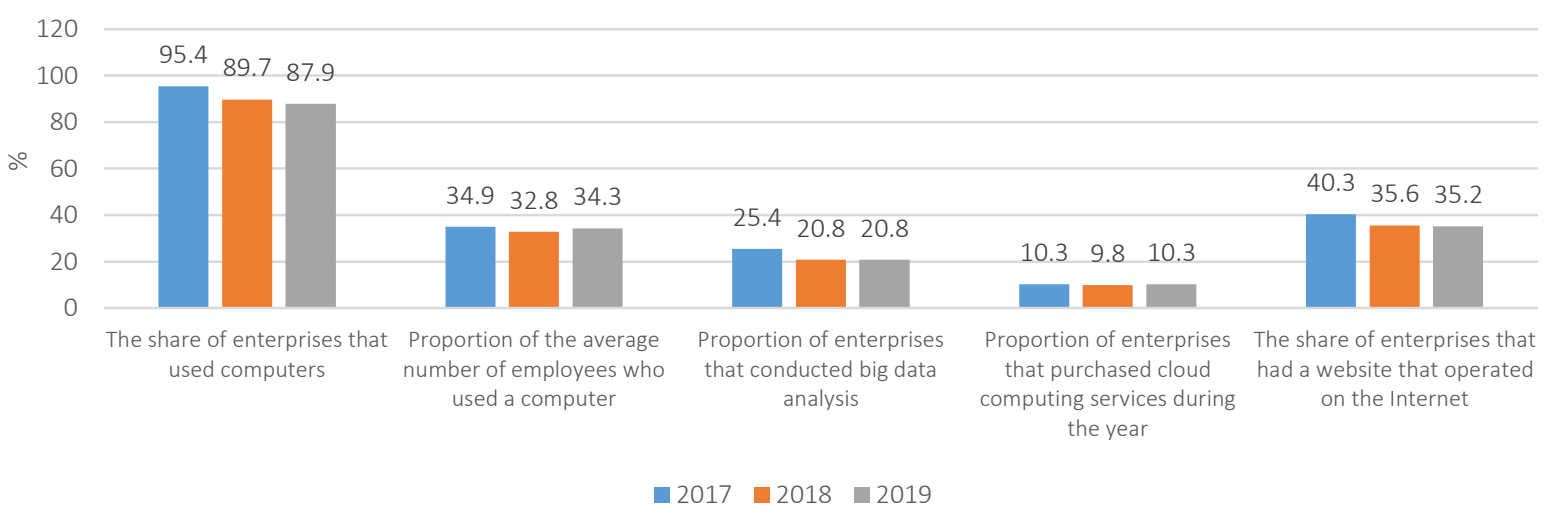

Figure 2. Dynamics of indicators of informatization of enterprises and organizations of Ukraine

Stage 2. The issue of the need to build a digital society has been appearing in Ukraine's strategic plans since the late 1990s when the world began to intensively introduce information technologies. In 1998, Ukraine adopted the Law "On the National Informatization Program" (The Verkhovna Rada of Ukraine, 1998), which defined the strategy of state policy to create a modern information infrastructure of Ukraine and defined the conditions for Ukraine's integration into the world information space in accordance with information geopolitics trends. Despite the measures taken, the process of digitalization in the country has progressed rather slowly. The problems of digital economy development in Ukraine are insufficient coverage of the territory by high-quality Internet and weak development of digital services. According to Pyshchulina (2020), all this indicates that Ukraine is not ready to implement the technologies of Industry 4.0, as the country has not yet completed the process of implementing Industry 3.0. As Makedon (2019) points out the level of automation in the Ukrainian industry is lower than average - in metallurgy it is about $50 \%$.

Figure 2 shows the dynamics of some indicators of the use of information and communication technologies at enterprises and organizations of the country for 2017-2019.

As can be seen from Figure 2, the digitalization level of Ukraine's economy has not significantly improved in 2017-2019. It even decreased in 2019 compared to 2017 by almost $8 \%$ in such a position as the use of computers by enterprises, by $18 \%$ in terms of the share of enterprises that used Big
Data Analysis, by $12.7 \%$ - in terms of the share of companies that have a functioning website.

Recently, the Government of Ukraine has taken various measures to implement and increase the intensity of the digitalization of society. Thus, to form and implement state policy in the field of digitalization, digital economy, digital innovation and information society development, the Ministry and Committee for Digital Transformation of Ukraine (2021) were established, the goals of which by 2024 are to ensure: $100 \%$ accessibility of public services to citizens and businesses online; 95\% of the population, social facilities and major highways with high-speed Internet; involvement of 6 million Ukrainians in the digital skills development program; the share of IT in the country's GDP is at $10 \%$.

In 2020, changes were approved in the Concept of Development of the Digital Economy and Society of Ukraine for 2018-2020 and it was noted that trends in increasing the digitalization of society are: bridging the digital divide through the development of digital infrastructures; development of digital competencies; introduction of the concept of digital workplaces; digitalization of the real sector of the economy; implementation of digital transformation projects; ensuring the necessary level of the general security of citizens; reforming the education system; digitalization of health care; digital transformation of tourist activity; introduction of e-democracy; introduction of digital technologies to improve the environmental situation; introduction of the concept of smart cities; development of the non-cash economy; harmoni- 
zation with European and world scientific initiatives; digitalization of public administration.

According to Pyshchulina (2020), the factors that affect the process of digital transformation of society and limit its intensity are divided into external barriers, resource constraints, and human potential (Table 3).

Table 3. Characteristics of factors that hinder the development of digitalization of society in Ukraine

\begin{tabular}{|c|c|}
\hline $\begin{array}{c}\text { The name } \\
\text { of the } \\
\text { factor }\end{array}$ & Characteristics of the factor \\
\hline $\begin{array}{l}\text { External } \\
\text { barriers }\end{array}$ & $\begin{array}{l}\text { Shortage of digital solutions that take into } \\
\text { account the specifics of the company's business; } \\
\text { availability of unstructured, contradictory data; } \\
\text { underdeveloped information infrastructure and } \\
\text { digital trust infrastructure; lack of standards for } \\
\text { the use of digital technologies; insufficiency of } \\
\text { legal regulation of relations in the digital economy; } \\
\text { insufficient security of data confidentiality and } \\
\text { protection against cybercrime. }\end{array}$ \\
\hline $\begin{array}{l}\text { Resource } \\
\text { constraints }\end{array}$ & $\begin{array}{l}\text { Lack of investment resources for the development } \\
\text { and implementation of innovations; high cost } \\
\text { of digital technology projects; high operating } \\
\text { costs of systems using digital technologies; lack } \\
\text { of opportunities for cooperation with other } \\
\text { enterprises and scientific organizations. }\end{array}$ \\
\hline $\begin{array}{l}\text { Human } \\
\text { capital }\end{array}$ & $\begin{array}{l}\text { Shortage of qualified personnel; low information } \\
\text { technology competence and digital culture } \\
\text { of users of Internet technologies and Internet } \\
\text { services; reluctance of staff and/or management } \\
\text { to change the usual forms of work. }\end{array}$ \\
\hline
\end{tabular}

Stage 3. The analysis showed that all countries-leaders in the field of digitalization consider education and innovation as the main driving forces of digi- talization of society and are increasingly introducing digital technologies in the field of education.

To study the trends of digitalization in education, it is proposed to use the method of decomposition of WDCR and analyze the dynamics of the digital competitiveness level of Ukraine by components of WDCR (Figure 3).

Thus, according to the knowledge component, Ukraine's place among the countries of the world will increase in 2020 by 2 points compared to the previous year, and by 6 points compared to 2016 . In addition, Ukraine occupies the highest-ranking positions for this component, so it is the knowledge component that largely forms the WDCR.

If one looks at the decomposition of the knowledge component into sub-factors, it can be seen that the training and education sub-factor also occupies the highest positions among the other two components in the formation of the WDCR (Figure 4).

As can be seen from Figure 4, the rating of the sub-factor training and education is the highest and in 2020 increased by 2 positions compared to 2019. Given the method of constructing WDCR, according to which each component and sub-factor has equal value, it is education that supports the level of digitalization of the country and acts as the dominant core in the process of digitalization.

In 2018, within the framework of the Paris Communiqué, European countries formed the

Source: IMD World Competitiveness Center (2020).

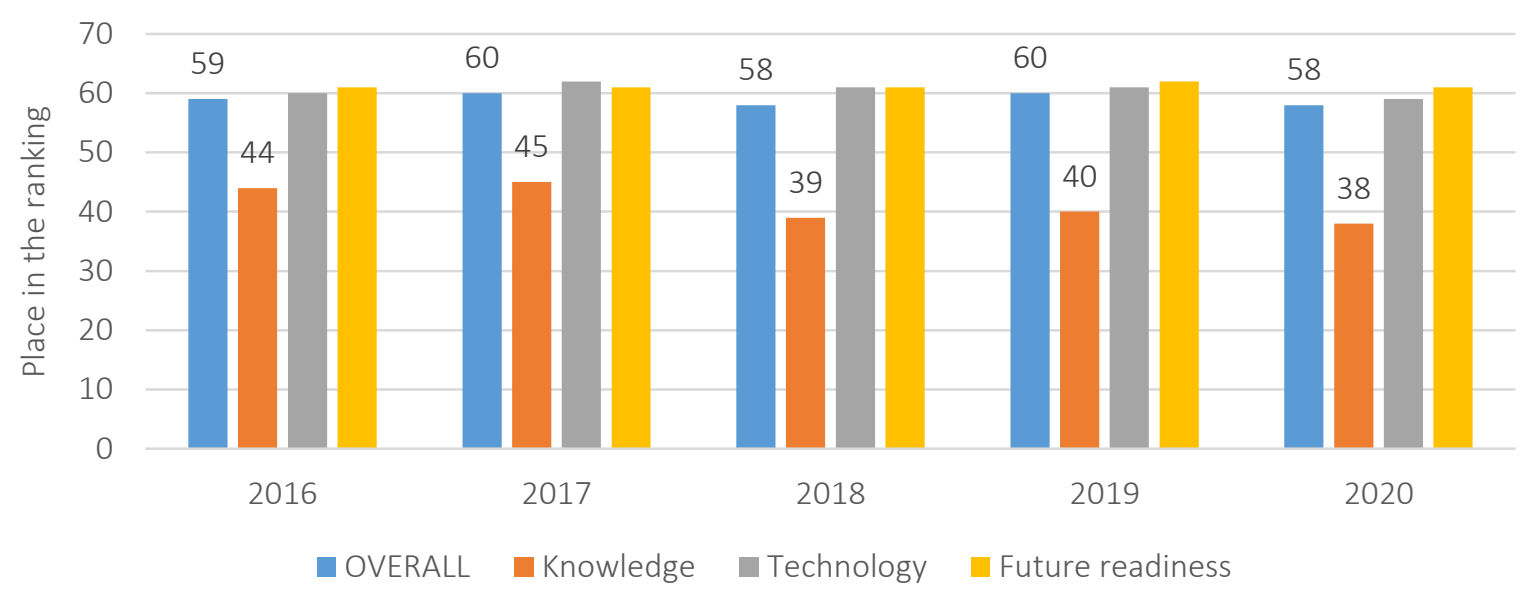

Figure 3. Dynamics of places of digital competitiveness rating components of Ukraine 

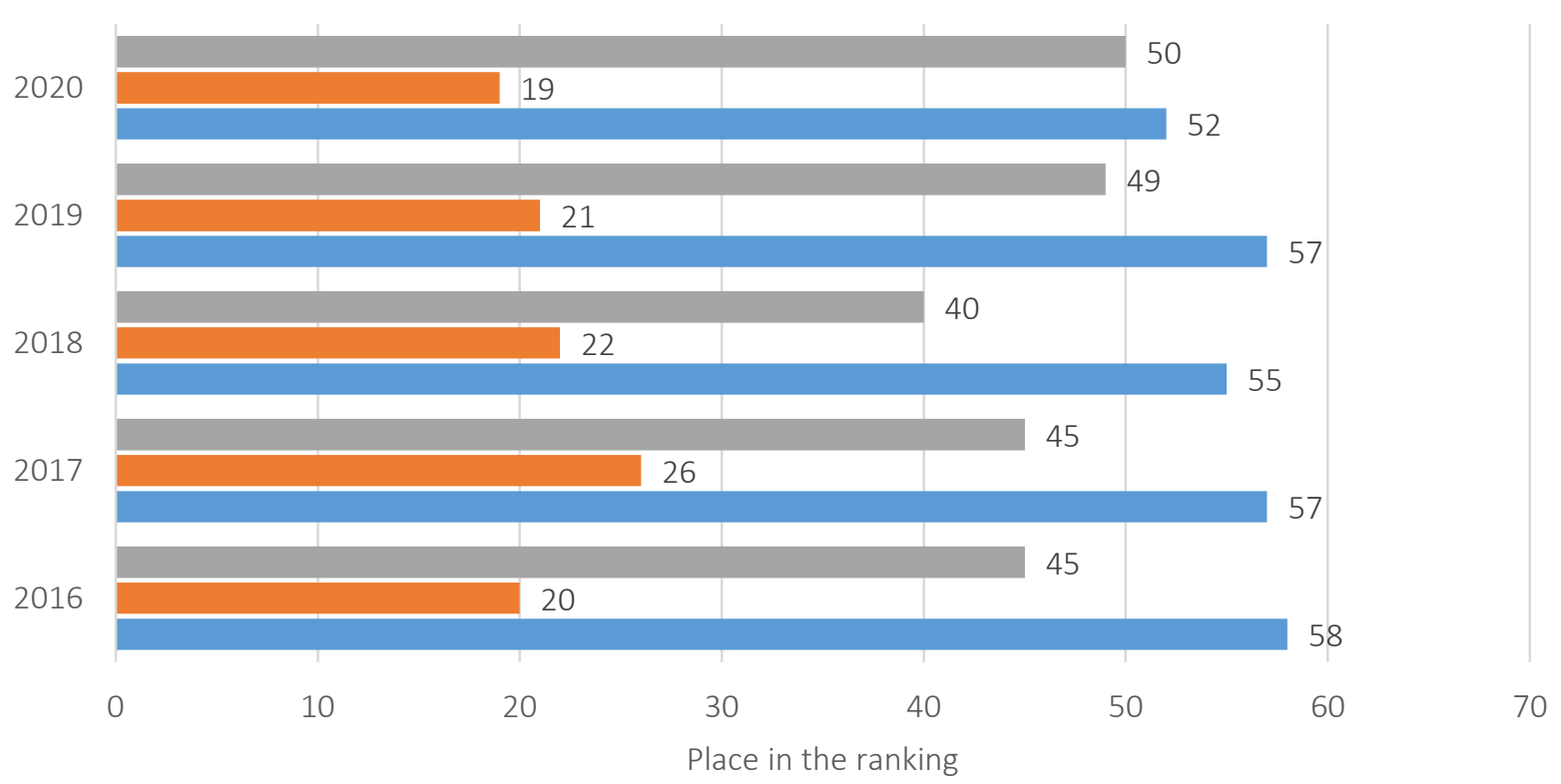

- Scientific Concentration $\quad$ Training and Education $\quad$ Talent

Figure 4. Dynamics of Ukraine's place by sub-factors of the knowledge component

values of the European Higher Education Area: academic freedom, integrity, institutional autonomy, participation of students and academic staff in government. They also singled out 10 principles for improving the process of teaching and learning, the essence of which is that education in the HEI forms a personality, is student-centered, based on the requests of interested stakeholders (Community for learning and teaching, 2021).

Based on these values and principles, the main trends of modern education are formed. Among these trends, special attention is paid to the digitalization of education through the creation of computer classes, Wi-Fi distribution, creation of online libraries, online courses, creation of student portals and depositories, introduction of e-portfolio, online exams and tests, etc.

The Government of Ukraine is also working on the implementation of the digital transformation of education and to implement this area, the Ministry of Education and Science of Ukraine decided to approve the Concept of Digital Transformation of Education and Science of Ukraine in 2021 (InfoCity, 2020). In 2020, the Strategy for the Development of Higher Education in Ukraine for 2021-2031 was developed, which states that mod- ern education lags behind the processes of digitalization, and more needs to be done to take advantage of the tools and strengths of new technologies while solving problems on possible abuses such as cyber intrusion and privacy issues (Ministry and Committee for Digital Transformation of Ukraine, 2021).

Thus, Figure 5 shows the main vectors of development of modern education in the direction of digitalization.

Speed means that because learning is subject to modern change, the usual accumulation of knowledge loses its relevance. Motivation and enthusiasm show that teachers become coordinators, guiding students both online and offline. The availability of materials in real time is aimed at simplifying the process of acquiring new knowledge. Interdisciplinary content shows that there is a combination of knowledge from different walks of life and the integration of the interests of different groups of stakeholders.

Stage 4. The digitalization of higher education depends on the entrepreneurial activity of specific IAU, which should develop concepts of digitalization of all types of their activities. 


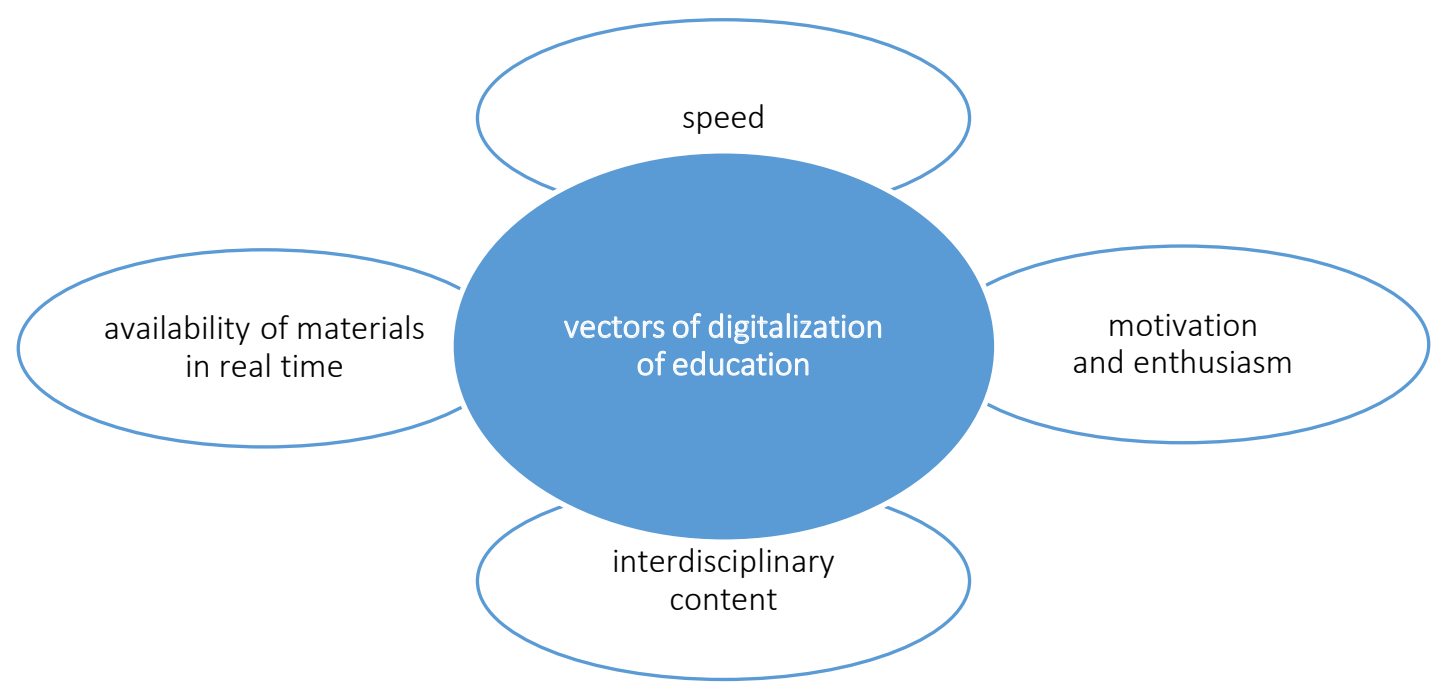

Figure 5. Vectors of digitalization of Ukrainian education

An effective concept of digitalization of HEI should be formed to create a digital environment and digital culture of the university.

The main tasks of the concept are:

1. Formation of digitalization strategy, tactical action plan, building a system of key performance indicators (KPI). To do this, it is necessary to determine the real and potential resources of the HEI in accordance with its business process/area of activity, the definition of achievable benchmarks (KPI) and means, ways and tools for their implementation.

2. Continuous training and motivation of staff to acquire the latest digital skills. This means using employee-driven management and creating an environment that develops the ability and willingness of staff to think creatively, be open to information innovations and implement them in the educational and scientific process.

3. Abandonment of outdated technologies. To do this, it is necessary to abandon, first of all, the old stereotypes of educational, scientific, international, and other activities of the HEI, to move from "competition technology" between departments, faculties, etc., to work on the principle of "joint efforts".

According to these tasks, the strategy of digitalization of the activities of Simon Kuznets Kharkiv
National University of Economics (S.Kuznets KhNUE) contains the following: a significant improvement in the quality of all processes and activities of the university based on the introduction of information and communication technologies and infrastructure, formation of a safe digital environment to create key conditions for training personnel for the digital economy, and development of innovative activities of the university, increasing its competitiveness in the national and international educational space.

It is proposed to build a digitalization strategy for S.Kuznets KhNUE in accordance with its main activities, namely educational, scientific and technical, marketing, and international ones (Figure 6).

This approach makes it possible to shape the digital culture of the university as a system of balanced relationships between the main and supporting departments of the university. The latter increases the efficiency of digitalization processes by enhancing the degree of their controllability.

The analysis practice of functioning of innovative-active universities of the world and Ukraine (Etzkowitz \& Zhou, 2008; Raievnieva et al., 2020; Shabanov \& Shorohova, 2009; Van Vught, 1999) allowed to form innovative and indicative measures of digitalization of S.Kuznets KhNUE as a set of tactical tasks according to the selected types of activity, namely: 


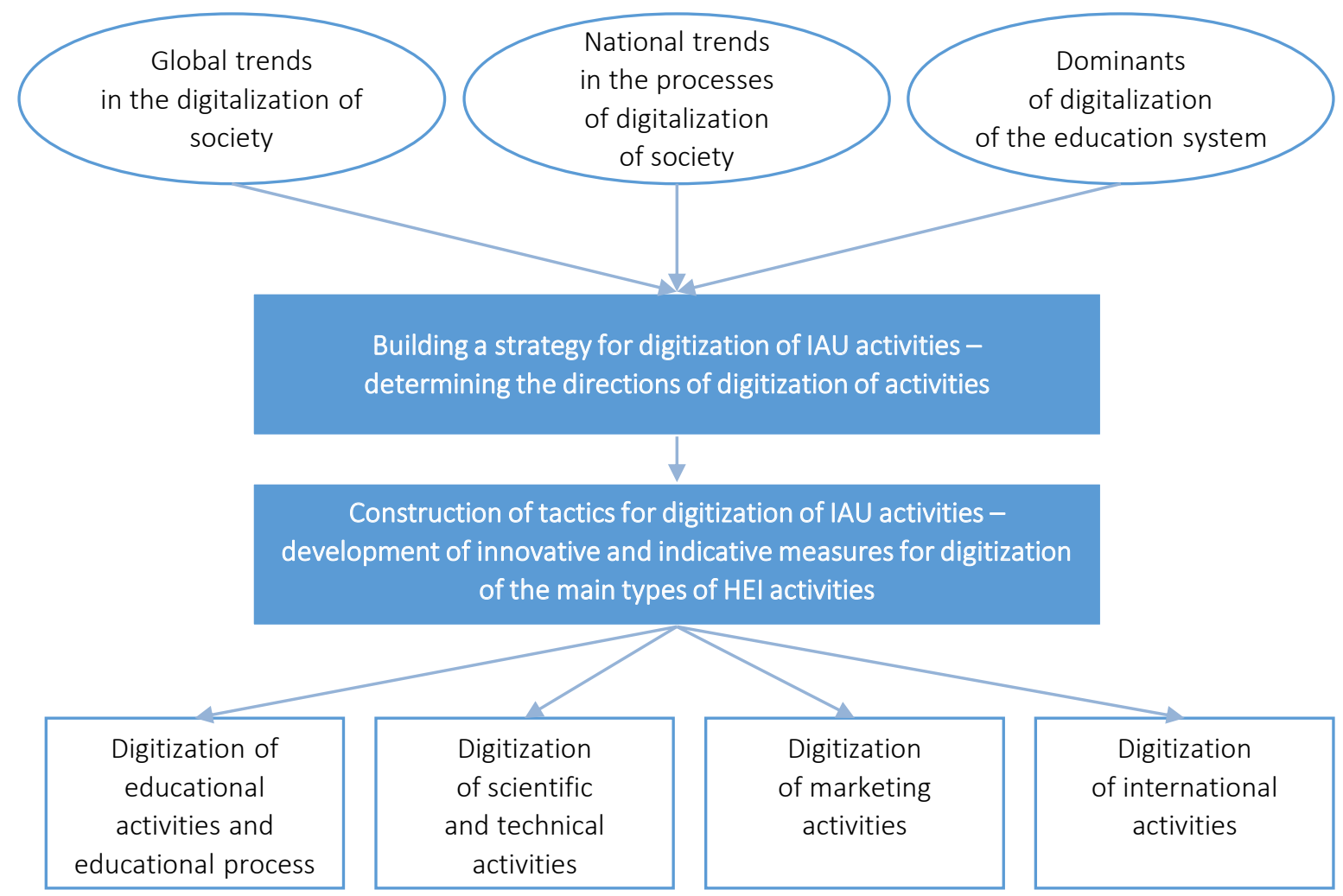

Figure 6. Components of the digitalization strategy of an innovative-active university S.Kuznets KhNUE

4. Digitization of educational activities and the educational process is:

- creation of basic information services used in the educational process (video screens for training sessions, cloud technologies for storage and data exchange, etc.);

- creation of a digital library (provides students or teachers access to scientific literature from any device, regardless of location and time of day) with tools for scientometric evaluation of scientific performance and publication activity of teachers and staff of the university;

- informatization of research project management processes, procurement, interaction with applicants and students, etc.;

- creation and application of information and communication technologies and platforms aimed at strengthening the quality of the educational process;
- using analytics to identify student learning outcomes and rank them;

- creating a system of feedback with students, studying their opinions and suggestions, evaluating teachers, the quality of the curriculum, the need for certain educational and professional programs, etc.

Further development of digitalization is the creation of digital campuses. Performers are department of e-learning tools, research sector, library, quality assurance, and innovative development department.

5. Digitization of scientific and technical activities is focused on:

- creation of special services for scientists that provide presentation and publication of research results on the Internet;

- informatization of publishing processes of magazines, including open access; 
- analysis of closed databases of publishing houses, open access to journals and sources on the Internet;

- use of information technologies for monitoring real-time publications;

- ensuring the quality of scientific content, in particular, creation of intelligent anti-plagiarism systems;

- informatization of the process of determining citation indices of articles, impact factors of publications, etc.

Performers are library, publishing house S.Kuznets KhNUE, quality assurance and innovative development department, research sector, and methodical department.

\section{Digitization of marketing activities is:}

- use of digital technologies to inform applicants on various issues of the educational process, which is important for both domestic entrants and potential foreign applicants;

- use of new interaction methods with employers;

- constant screening of the university reputation and formation of a positive image of the HEI in social and professional Internet networks;

- stimulating the creation of new digital communities and innovations at all stages of the educational cycle, etc.;

Performers are department of marketing and corporate communication, department of student employment and interaction with business structures, and department of e-learning tools.

\section{Digitization of international activities is:}

- integration of IAU to the level of European universities;

- creation of network universities without borders;
- increasing the competitiveness level of HEI at the international level;

- introduction of foreign experience of digital inclusion in the practical activities of HEI;

- improving the position of HEI in international rankings.

The prospect is to create a network university without borders. Performers are quality assurance and innovative development department, and department of international relations.

An extensive network of information, digital technologies, and services forms the digital environment of the IAU. This presupposes the need to build an effective information corporate scientific and educational system. In S.Kuznets KhNUE, this system is, on the one hand, the basis, and on the other hand, a tool for improving the quality of digitalization processes of all types of activities of the HEI through the creation of a system of electronic document management and electronic signature; information subsystems of directorates and services of the HEI; information support of the HEI control system; corporate information security system; teacher's personal account; student's personal account; information system for assessing the quality of education; electronic library platforms; individual schedule of classes; electronic management of assessment and monitoring of attendance.

All this makes it possible to significantly enhance the quality of the university interaction with the main stakeholders, namely students, applicants, potential and real employers, representatives of the state, regional and local authorities.

That is, the proposed tasks of digital culture and elements of the digital environment are triggers for the innovative development of S.Kuznets KhNUE and contribute to strengthening its competitive advantages in the national and international educational market.

The digitalization of the educational process, as a key activity of the HEI, is a combination of modern digital platforms, new information and educational technologies, and progressive forms of organizing the educational process. 
Evolutionary vector of transformation of forms of learning

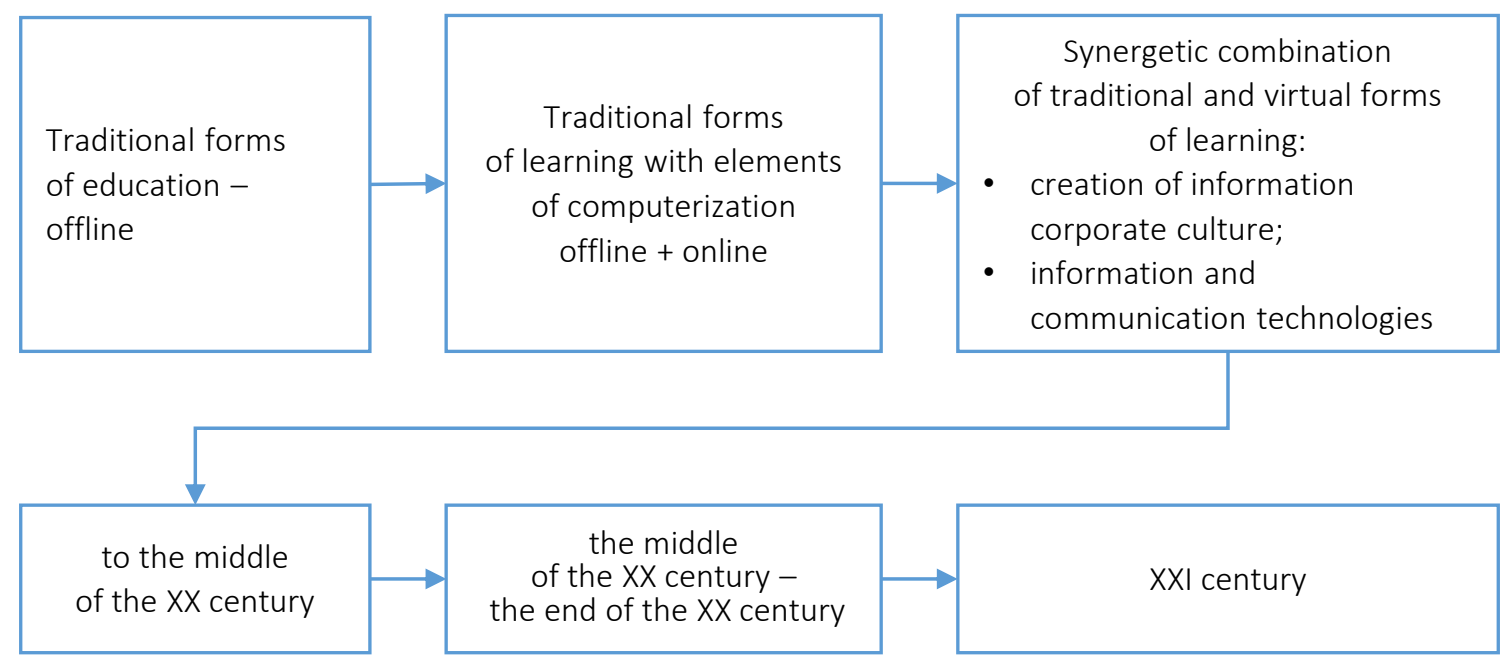

Figure 7. Transformation of education forms

Figure 7 shows the transformation of forms of education in accordance with the level of digital culture.

Today the organization of the educational process is at the stage of combining traditional and virtual forms of education, characterized by the search for new and transformation of traditional forms and methods of teaching that will improve the quality of specialists' training in various specialties based on information and communication technologies. All this confirms the need to create an information corporate culture, which on the one hand, involves the formation and expansion of information skills of both students and teachers, on the other - information and communication readiness of HEI to effectively support information interaction between them. The latter involves the presence of a set of information, digital online technologies that allow maintaining the high quality of the educational process.

Given the spread of the Covid-19, all educational institutions in Ukraine faced unprecedented challenges and the need to find the optimal combination of traditional and virtual forms of learning for HEI (Figure 8).

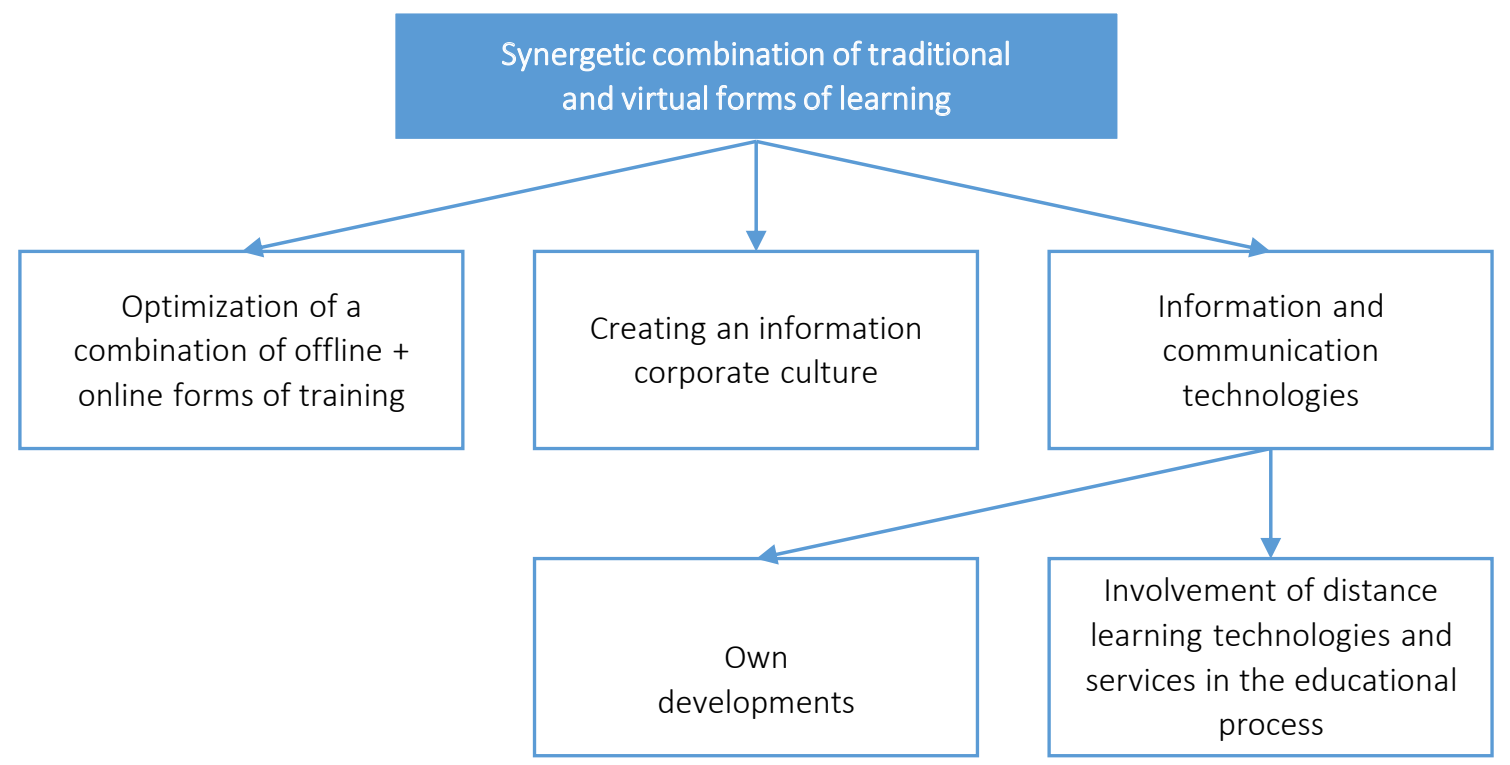

Figure 8. The scheme of combining traditional and virtual forms of learning 


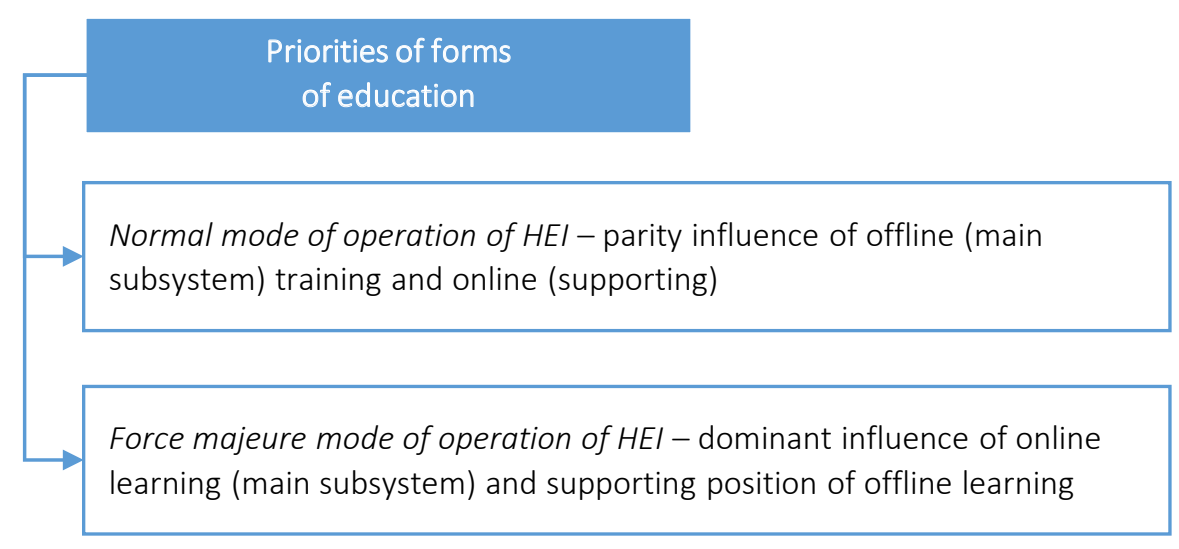

Figure 9. Directions of priority forms of education

The traditional form of training involves the formation of information and communication system, which, in turn, is the main innovative component in the formation of information and corporate culture of HEI. The introduction of traditional and virtual forms of education is reflected in the combination of offline and online forms of education, which depends on the level of stability of the external environment in which the university operates.

Research in this direction allowed to determine the normal and force majeure modes of operation and the corresponding priorities of forms of education (Figure 9).
Thus, the challenge of the Covid-19 pandemic in the higher education system in 2020 was the impetus for a radical digitalization of the educational environment. The transition to virtual networks from classrooms, which happened suddenly and on a massive scale, sharpened the practical implementation of issues that have been the subject of debate among scientists until now.

In the period of combining traditional and virtual forms of education, at S.Kuznets KhNUE, the educational process is implemented through the use of personal educational system (PES). PES of S.Kuznets KhNUE is a platform that covers all electronic training courses of the university, de-

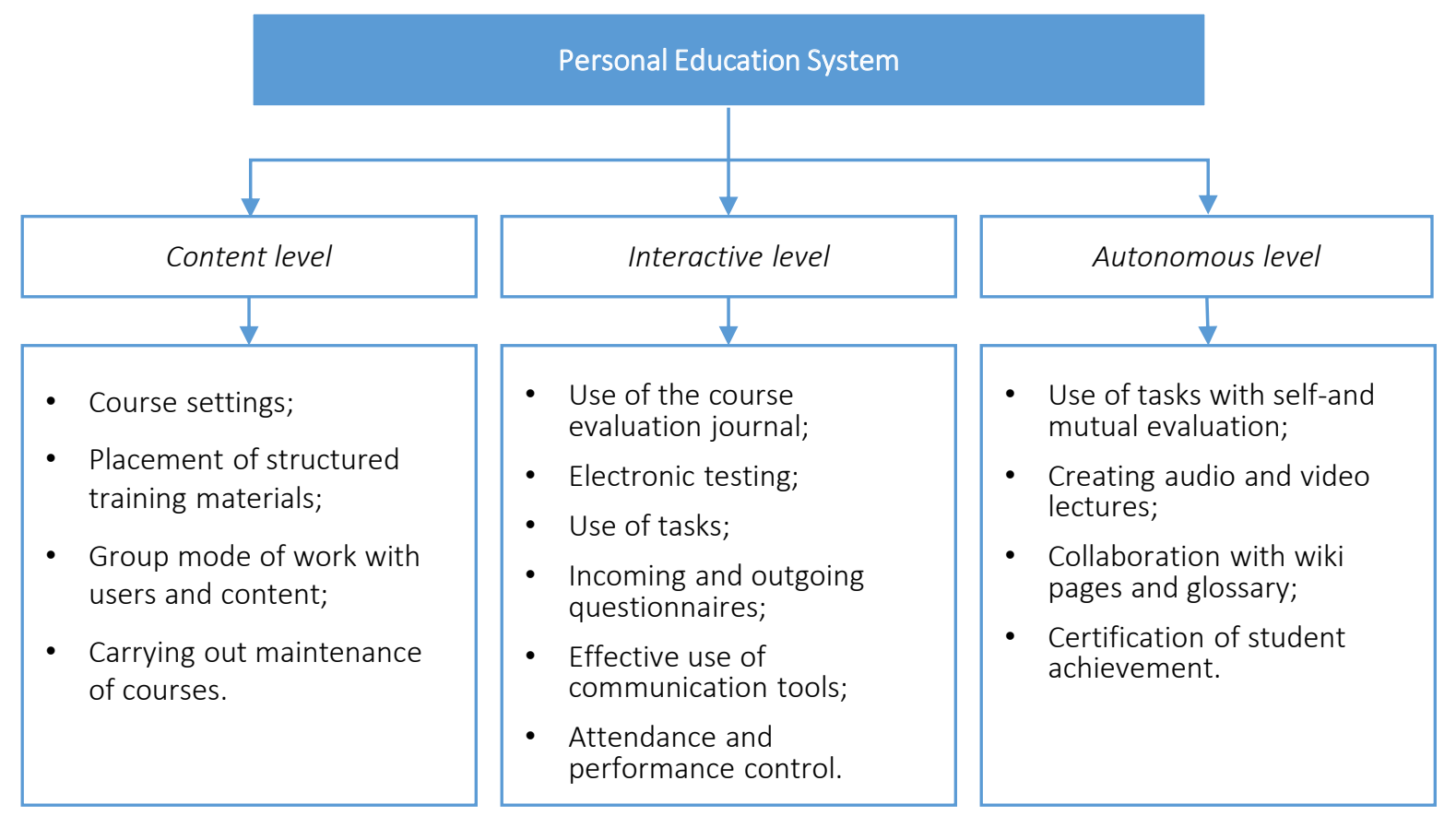

Figure 10. Three-level model of personal educational system in S.Kuznets KhNUE 
Table 4. Monitoring student learning outcomes for 2018-2021

\begin{tabular}{|c|c|c|c|c|c|c|}
\hline \multirow[b]{2}{*}{ Specialty } & \multirow[b]{2}{*}{ Course } & \multirow{2}{*}{$\begin{array}{l}\text { Number of applicants } \\
\text { for higher education } \\
\text { at the beginning of the } \\
\text { semester }\end{array}$} & \multicolumn{2}{|c|}{$\begin{array}{c}\text { Applicants with quality } \\
\text { performance }\end{array}$} & \multicolumn{2}{|c|}{$\begin{array}{l}\text { Applicants who received } \\
\text { satisfactory marks }\end{array}$} \\
\hline & & & Number & $\begin{array}{c}\% \text { of the total } \\
\text { number on the } \\
\text { course }\end{array}$ & Number & $\begin{array}{c}\% \text { of the total } \\
\text { number on the } \\
\text { course }\end{array}$ \\
\hline \multicolumn{7}{|c|}{ 2018-2019 academic year (the main form of teaching is traditional) } \\
\hline \multirow{2}{*}{ Economics } & 1 & 164 & 43 & 26.22 & 121 & 73.78 \\
\hline & 2 & 163 & 69 & 42.33 & 94 & 57.67 \\
\hline \multicolumn{7}{|c|}{ 2019-2020 academic year (the main form of teaching is the combination of traditional and virtual) } \\
\hline \multirow{2}{*}{ Economics } & 1 & 188 & 49 & 26.06 & 139 & 73.94 \\
\hline & 2 & 152 & 46 & 30.26 & 106 & 69.74 \\
\hline \multicolumn{7}{|c|}{ I semester 2020-2021 academic year (the main form of teaching is virtual) } \\
\hline \multirow{2}{*}{ Economics } & 1 & 229 & 70 & 30.57 & 159 & 69.43 \\
\hline & 2 & 173 & 55 & 31.79 & 118 & 68.21 \\
\hline
\end{tabular}

signed to create and manage a virtual learning environment to share learning materials, conduct classes online and assess students' knowledge.

The site of PES is built on the basis of the Moodle platform. Moodle is a free and open-source learning management system. It acts as an effective tool for interaction between the teacher and students, is suitable for the organization of traditional distance learning courses, and can serve as a supplement during full-time learning.

Since the functionality of the Moodle platform is wide enough, for the gradual use of the system tools by teachers at S.Kuznets KhNUE in order to improve the quality of education, three levels of PNS functionality have been introduced (Figure 10).

The use of the Moodle system during the period of the virtual form of education allowed for the transition to an interactive level, which indicates the strengthening of the digitalization of the educational process.

A high level of quality of education is a factor in the competitiveness of any HEI, therefore, monitoring the quality of the educational process, especially in the context of online learning, is an indicator of the readiness of HEI to function in the new conditions of a digital society.

In S.Kuznets KhNUE, the quality assurance and innovative development department constantly evaluates the quality of the educational process for all educational programs. Table 4 shows the results of monitoring for students of 1-2 courses of the specialty "Economics" in different learning conditions.

The transition from the traditional form of education in 2018-2019 to mixed in 2019-2020 and to online learning in 2020-2021 did not worsen the quality of students' progress, which showed the readiness of S.Kuznets KhNUE to reorganize education in force majeure circumstances. The introduction of digitalization elements has made the educational process mobile, differentiated, and individual. The use of information and communication technologies makes educational activities adaptive, interactive, and manageable.

\section{DISCUSSION}

The emergence of the phenomenon of a digital society and economy has significantly changed all spheres of civilization's life, in particular the system of higher education. Today, universities are faced with the need to find effective innovative ways, means, and ways that will allow them to adapt to the new system of social and economic relations and at the same time not lose their key role in teaching and research.

The emergence in the late XX-early XXI century of the concept of an entrepreneurial university, the digital university is the result of such efforts. By supporting the imperatives of these concepts, a modern university considers its competitiveness as a result of entrepreneurial activity in the field of science and education, innovative and active efforts to anticipate changes in trends in the 
development of society and the economy. That is why the systemic digitalization of the processes of functioning of the university, the spheres of its activity, has currently a high level of relevance.

In this context, a significant role is played by the concept of digitalization of university activities, the development of which is the work of many scientists. The paper proposes to consider the concept of digitalization as the mutual influence of two components - the digital culture of the university and its digital environment. Directed culture is formed by the strategy of digitalization of the main areas of the university activities, which allows to look at the digital culture from a systemic standpoint, and form a system of interaction between the main and supporting subsystems of the university. This will increase the manageability of the digitalization process and form the basis for the development of an effective digital environment. The essence of the latter is formed by an information corporate educational and scientific system, which is considered both an environment and a tool for the diffusion of the latest digital technologies and shells into all the areas of the university's activity.

Thus, the transition of the university to the digital level of its activities will ensure its active adaptation to the trends in the transformation of the higher education system of the XXI century. However, such a radical transformation can be carried out only in the conditions of resource and mental readiness of the university, which are the characteristics of an innovative-active university. The widespread introduction of digitalization tools in educational, scientific and technical, marketing, international activities presuppose the presence of creative, open to innovations, scientific and pedagogical personnel, the sufficiency of financial support for the implementation and support of the latest digital technologies and information services.

Thus, there should be a program of state support for such initiatives on a tender basis for the Ukrainian universities.

\section{CONCLUSION}

Digitalization and the formation of a digital society are a source of global transformations that require adaptation of the world's higher education system to them and the introduction of modern digital technologies and information services into the practice of universities. It has been proved that the digitalization of university activities depends on the digital maturity of society, the widespread use of digital technologies and skills in the economy. The triggers and limitations of digitalization of the Ukrainian society are highlighted, the ranking place of Ukraine among the countries of the world according to the main indicators of digitalization is determined.

The methodological basis of the study is the concept of a digital university, which substantiates the need for the formation of a digital environment and digital culture of universities. It is proposed that the formation of digital culture involves the development of a digitalization strategy for the types of activities of the university: educational, scientific and technical, marketing, and international. This allows systematically presenting the tasks of effective digital transformation of the university and speeding up the process of making managerial decisions in this direction. The digital environment is understood as an information corporate scientific and educational system, which, on the one hand, creates an information basis for the effective interaction of structural units of universities, and on the other, acts as a channel for the dissemination of the latest digital technologies in all types of university activities, primarily in education.

A methodical approach has been developed that makes it possible to form an effective strategy for digitalization of the main areas of activity of the S.Kuznets KhNUE on the basis of determining the possibilities of the external environment - the digital maturity of society and the economy, the resource readiness of the university. 
To detail the strategic directions of digitalization of the university's activities, innovative and indicative measures have been developed in the form of a complex of tactical tasks; structural units responsible for their implementation have been identified. The developed tasks allow in the future forming a system of key performance indicators to increase the level of controllability of digital processes.

\section{AUTHOR CONTRIBUTIONS}

Conceptualization: Volodymir Ponomarenko, Olena Rayevnyeva.

Data curation: Volodymyr Yermachenko, Iryna Aksonova, Olha Brovko.

Formal analysis: Volodymir Ponomarenko, Olena Rayevnyeva, Iryna Aksonova, Olha Brovko.

Investigation: Volodymir Ponomarenko, Olena Rayevnyeva, Volodymyr Yermachenko, Iryna Aksonova, Olha Brovko.

Methodology: Volodymir Ponomarenko, Olena Rayevnyeva, Iryna Aksonova, Olha Brovko.

Project administration: Olena Rayevnyeva.

Resources: Volodymyr Yermachenko, Iryna Aksonova, Olha Brovko.

Software: Iryna Aksonova, Olha Brovko.

Validation: Volodymir Ponomarenko, Olena Rayevnyeva, Iryna Aksonova, Olha Brovko.

Visualization: Iryna Aksonova, Olha Brovko.

Writing - original draft: Volodymir Ponomarenko, Olena Rayevnyeva, Iryna Aksonova, Olha Brovko. Writing - review \& editing: Volodymir Ponomarenko, Olena Rayevnyeva, Iryna Aksonova, Olha Brovko.

\section{ACKNOWLEDGMENT}

The following materials were used in writing this paper: Development of methodological and modelinformation support for the construction of an innovative type university on the basis of education quality and anti-corruption (state registration number: 0120U102152).

\section{REFERENCES}

1. Areshonkov, V. (2020). Tsyfrovizatsiia vyshchoi osvity: vyklyky ta vidpovidi [Digitalization of higher education: challenges and answers]. Visnyk NAPN Ukrainy - Bulletin of the National Academy of Pedagogical Sciences of Ukraine, 2(2), 1-6. (In Ukrainian). https://doi.org/10.37472/2707305X-2020-2-2-13-2

2. Babin, E. N. (2018). Tsifrovizatsiya universiteta: postroenie integrirovannoi informatsionnoi sredy [University digitalization: building an integrated information environment]. Universitetskoe upravlenie: praktika i analiz - University Management: Practice and Analysis, 22(6), 44-54. (In Russian). https:// doi.org/10.15826/umpa.2018.06.057

3. Bakumenko, L.P., \& Minina, E.A. (2020). Mezhdunarodnyy indeks tsifrovoy ekonomiki i obshchestva
(I-DESI): tendentsii razvitiya tsifrovykh tekhnologiy [International Index of Digital Economy and Society (I-DESI): Trends in the Development of Digital Technologies]. Statistika i ekonomika - Statistics and Economics, 17(2), 40-54. (In Russian). https://doi. org/10.21686/2500-3925-2020-240-54

4. Center of economic recovery. (2021). Natsionalna ekonomichna strategiia 2030 [National Economic Strategy 2030]. (In Ukrainian). Retrieved from https://nes2030. org.ua/

5. Community for learning and teaching. (2021). Piat trendiv vyshchoi osvity u Yevropi [Five trends in higher education in Europe]. (In Ukrainian). Retrieved from http:// gohigher.org/5_trendiv_vyshchoi_ osvity_u_yevropi
6. Dutta, S., \& Lanvin, B. (2020). The network readiness index 2020. Portulans Institute and STU25. Retrieved from https:// networkreadinessindex.org/wpcontent/uploads/2020/10/NRI2020-Final-Report-October2020. pdf

7. Dyba, M. I., \& Gernego, I. O. (2018). Didzhytalizatsiia ekonomiky: svitovyi dosvid ta mozhlyvosti rozvytku v Ukraini [Digitalization of the economy: world experience and opportunities for development in Ukraine]. Finansy Ukrainy - Finance of Ukraine, 7, 50-63. (In Ukrainian). Retrieved from https://ir.kneu.edu. ua:443/handle/2010/27260

8. Etzkowitz, H., \& Zhou, C. (2008). The Triple Helix: University-Industry-Government Innovation In Action. London: Routledge. Retrieved 
from https://www.routledge.com/ The-Triple-Helix-UniversityIndustryGovernment-Innovationand-Entrepreneurship/EtzkowitzZhou/p/book/9781138659490

9. Evergreen. (2020). Ponyatie didzhitalizatsii biznesa: sfery i neobhodimost [Business digitalization concept: spheres and necessity]. (In Russian). Retrieved from https:// evergreens.com.ua/ru/articles/ business-digitalization.html

10. Global connectivity index. (2020). GCI Ranking Table. Retrieved from https://www.huawei.com/minisite/ gci/en/country-rankings.html

11. Golovenchik, G. G. (2018). Reytingovyy analiz urovnya tsifrovoy transformatsii ekonomik stran EAES i ES [Rating analysis of the level of digital transformation of the economies of the EAEU and EU countries]. Tsifrovaya transformatsiya - Digital transformation, 2(3), 5-18. (In Russian). Retrieved from https://dt.giac.by/jour/article/ view/75/61\#

12. Habib, M. N., Jamal, W., Khalil, U., \& Khan, Z. (2021). Transforming universities in interactive digital platform: case of city university of science and information technology. Education and Information Technologies, 26, 517-541. https://doi. org/10.1007/s10639-020-10237-w

13. IMD World Competitiveness Center. (2020). Rankings. Retrieved from https://www.imd.org/wcc/ world-competitiveness-centerrankings/world-digital-competitiveness-rankings-2020/

14. InfoCity. (2020). Dell Technologies: globalnaya pandemiya uskoryaet tsyfrovuyu transformatsiyu [Dell Technologies: Global Pandemic Accelerates Digital Transformation]. (In Russian). Retrieved from https://infocity.az/2020/10/ dell-technologies-globalnayapandemiya-uskoryaet-cifrovuyutransformaciyu/

15. International Telecommunication Union. (2017). ICT Development Index 2017. Retrieved from https:// www.itu.int/net4/ITU-D/idi/2017/ index.html

16. Johnston, B., MacNeill, S., \& Smyth, K. (2018). Exploring the Digital
University: Developing and Applying Holistic Thinking. In Conceptualising the Digital University. Digital Education and Learning. Palgrave Macmillan. https://doi. org/10.1007/978-3-319-99160-3_3

17. Jones, C., \& Goodfellow, R. (2012). The "Digital University": Discourse, Theory, and Evidence. International Journal of Learning and Media, 4(34), 59-63. https://doi.org/10.1162/ IJLM_a_00103

18. Kadyrbaeva, A. (2018). Tsifrovizatsiya $v$ obuchenii personala [Digitalization in personnel training]. Higher School of Economics. (In Russian). Retrieved from https://docplayer. ru/120705582-Cifrovizaciya-vobuchenii-personala.html

19. Kokh, L.V., \& Kokh, Ju.V. (2019). Analysis of existing approaches to measuring the digital economy. Nauchno-tehnicheskie vedomosti SPbGPU. Ekonomicheskie naukiScientific and technical statements of SPbSPU. Economic science, 12(4), 78-89. (In Russian). https://doi. org/10.18721/JE.12407

20. Kolyadenko, S. V. (2016). Tsyfrova ekonomika: peredumovy ta etapy stanovlennia v Ukraini i u sviti [Digital economy: preconditions and stages of formation in Ukraine and in the world]. Ekonomika. Finansy. Menedzhment: aktualni pytannia nauky i praktyky - Economy. Finances. Management: current issues of science and practice, 6 , 105-112. (In Ukrainian). Retrieved from http://nbuv.gov.ua/UJRN/ efmapnp_2016_6_11.

21. Kononova, K. Yu. (2015). Informatsiina ekonomika: modeliuvannia evoliutsiinykh protsesiv [Information economics: modeling of evolutionary processes]. V.N. Karazin Kharkiv National University. (In Ukrainian). Retrieved from https://www. univer.kharkov.ua/images/redactor/ news/2016-05-27/kononova.pdf

22. Korotenko, O. (2020). Onlain-osvita: iak zdobuvaty znannia v epohu didzhytalizatsii [Online education: how to acquire knowledge in the age of digitalization]. Bazilik. (In Ukrainian). Retrieved from https:// bazilik.media/onlajn-osvita-iakzdobuvaty-znannia-v-epokhudidzhytalizatsii/
23. Kraus, N. M., Goloborodko, O. P., \& Kraus, K. M. (2018). Tsyfrova ekonomika: trendy ta perspektyvy avangardnogo harakteru rozvytku [Digital economy: trends and prospects of avant-garde development]. Efektyvna ekonomika - Efficient economy, 1. (In Ukrainian). Retrieved from http://www.economy. nayka.com.ua/?op=1\&z=6047

24. Liashenko, V. I., \& Vyshnevskyi, O. S. (2018). Tsyfrova modernizatsiia ekonomiky Ukrainy iak mozhlyvist proryvnogo rozvytku [Digital modernization of Ukraine's economy as an opportunity for breakthrough development]. Institute of Industrial Economics, National Academy of Sciences of Ukraine. (In Ukrainian). Retrieved from https:// iie.org.ua/wp-content/uploads/ monografiyi/2017/Lyashenko_ Vishnevsky_2018.pdf

25. Lukianenko, D., \& Stepanenko, O. (2018). Digital university: proekt rozbudovy tsyfrovoho universytetu $v$ DVNZ "Kyivskyi natsionalnyi ekonomichnyi universytet imeni Vadyma Hetmana" [Digital university: Digital university project of the university of Kyiv National Vadim Hetman University of Economics]. Kyiv National Vadim Hetman University of Economics. (In Ukrainian). Retrieved from https://ir.kneu.edu.ua/bitstream/ handle/2010/25986/ZE_2018_71. pdf? sequence $=1$ \&isAllowed $=y$

26. MacNeill, S., \& Johnston, B. (2016, December 13). The Digital University. Learning and Teaching Academy at the University of the Highlands and Islands. Retrieved from https:// ltauhi.wordpress.com/2016/12/23/ the-digital-university/

27. Makedon, I. (2019, September 12). Metallurgiya $v$ Ukraine avtomatizirovana na 50\% [Metallurgy in Ukraine is automated by 50\%]. GMK Center. (In Russian). Retrieved from https://gmk.center/ news/metallurgiya-v-ukraine-avtomatizirovana-na-50.

28. McCluskey, F. B., \& Lynn Winter, M. (2012). The Idea of the Digital University: Ancient Traditions, Disruptive Technologies and the Battle for the Soul of Higher Education. Policy Studies Organization. Retrieved from https://www.amazon.com/ 
Idea-Digital-University-TraditionsTechnologies/dp/1935907980

29. Ministry and Committee for Digital Transformation of Ukraine. (2021). Tsili do 2024 roku [Goals until 2024]. Retrieved from https://thedigital. gov.ua/

30. Ministry of Education and Science of Ukraine. (2020). Strategiia rozvytku vyshchoi osvity v Ukraini na 2021-2031 roky [Strategy for the development of higher education in Ukraine for 2021-2031]. Retrieved from https://mon.gov.ua/storage/ app/media/rizne/2020/09/25/ rozvitku-vishchoi-osviti-vukraini-02-10-2020.pdf

31. Ochs, T., \& Riemann, U. (2018). IT Strategy Follows Digitalization. In Encyclopedia of Information Science and Technology ( $4^{\text {th }}$ ed.). Hershey, PA: IGI Global.

32. OP.ua. (2021, February 5). Didzhytalizatsiia sfery osvity i nauky: strategiia MON [Digitalization of education and science: the strategy of the Ministry of Education and Science]. Retrieved from https:// op.ua/news/osvita-v-ukraini/didzhitalizaciya-sferi-osviti-i-naukistrategiya-mon

33. PwC. (2018). The 2018 digital university - Staying relevant in the digital age. Retrieved from https:// www.pwc.co.uk/assets/pdf/the2018-digital-university-stayingrelevant-in-the-digital-age.pdf

34. Pyshchulina, O. (2020). Tsyfrova ekonomika: trendy, ryzyky ta socialni determinanty [Digital economy: trends, risks and social determinants]. Razumkov Centre. (In Ukrainian). Retrieved from https://razumkov.org.ua/uploads/ article/2020_digitalization.pdf

35. Raievnieva, O. V., Azizova, K. M., \& Ostapenko, V. M. (2020). Innovatsiino-aktyvnyi universytet: pidgruntia vynyknennia ta osoblyvosti funktsionuvannia [Innovatively active university: the basis of origin and features of functioning]. Problemy ekonomiky - Problems of the economy, 4, 82-97. (In Ukrainian). https://doi.org/10.32983/22220712-2020-4-82-97

36. S.Kuznets KhNUE. (2018). Metodychne zabezpechennia rozrobky personalnykh navchalnykh system [Methodical support for the development of personal educational systems]. Retrieved from https:// pns.hneu.edu.ua/mod/url/view. php?id=143164

37. Schwab, K. (2019). The Global Competitiveness Report 2019. World Economic Forum. Retrieved from http://www3.weforum.org/docs/ WEF_TheGlobalCompetitivenessReport2019.pdf

38. Shabanov, A. G., \& Shorohova, T. I. (2009). Obrazovatelnaya sreda innovatsionnogo vuza [Educational environment of an innovative university]. Filosofija obrazovanija - Philosophy of Education, 1, 51-56. (In Russian). Retrieved from https://www.sibran.ru/journals/ issue.php?ID=120683\&ARTICLE_ ID $=128687$

39. State Statistics Service of Ukraine. (2020). Vykorystannia informatciino-komunikatciinykh tekhnologii na pidpryiemstvakh [The use of information and communication technologies in enterprises]. Retrieved from http://www.ukrstat.gov.ua/

40. The Verkhovna Rada of Ukraine. (1998). Zakon Ukrainy "Pro Nacionalnu programu informatyzatsii" [Law of Ukraine "On the National Informatization Program"]. Retrieved from https://zakon. rada.gov.ua/laws/show/74/98 \%D0\%B2\%D1\%80\#Text

41. United Nations. (2020). EGovernment Development Index. E-Participation Index. Retrieved from https://publicadministration. un.org/egovkb/en-us/Data/Country-Information/id/180-Ukraine

42. UN Economic and Social Council. (2020). Sovershenstvovanie izmereniya tsifrovizatsii: initsiativy mezhdunarodnykh organizasiy po kontseptualnym voprosam $i$ voprosam izmereniya [Enhancing the Measurement of Digitalization: Initiatives by International Organizations on Conceptual and Measurement Issues]. Retrieved from https:// unece.org/fileadmin/DAM/stats/ documents/ece/ces/2020/ECE_ CES_2020_3-2005706R.pdf

43. Van Vught, F. (1999). Innovative universities. Tertiary Education and Management, 5(4), 347-354.
Retrieved from https://www.tandfonline.com/doi/abs/10.1080/13583 883.1999 .9967001

44. Varlamova, M., \& Demianova, Yu. (2020). Osnovni tendentsii didzhytalizatsii u globalnomu vymiri [The main trends of digitalization in the global dimension]. Galytskyi ekonomichnyi visnyk - Galician Economic Bulletin, 63(2), 251-260. (In Ukrainian). https:// doi.org/10.33108/galicianvisnyk_ tntu2020.02.251

45. World Intellectual Property Organization. (2020). Global Innovation Index 2020. Retrieved from https:// www.wipo.int/global_innovation_index/en/2020/

46. Yevseiev, S., Ponomarenko, V., \& Rayevnyeva, O. (2017). Assessment of functional efficiency of a corporate scientific-educational network based on comprehensive indicators of quality of service. Information technology. Industry control systems, 6(2/90), 4-15. https://doi.org/10.15587/17294061.2017.118329

47. Yevseiev, S., Rayevnyeva, O., Ponomarenko, V., \& Milov, O. (2020). Development of methodological principles for the construction of a corporate information-educational system of innovative-active university in the framework of anti-corruption activities. EasternEuropean Journal of Enterprise Technologies, 5(2(107)), 6-28. https://doi.org/10.15587/17294061.2020.214895

48. Yevsieiev, S. P, Rzaiev, H. N., Ostapov, S. E., \& Nikolaienko, V. I. (2017). Otsinka obminu danymy v globalnykh obchysliuvalnykh merezhakh na osnovi kompleksnogo pokaznyka yakosti obslugovuvannia merezhi [Evaluation of data exchange in global computer networks based on a comprehensive indicator of network service quality]. Radioelektronika, informatyka, upravlinnia - Radio electronics, computer science, management, 1 , 115-128. (In Ukrainian). Retrieved from http://nbuv.gov.ua/UJRN/ riu_2017_1_16 